\title{
ALDER-ASH AND WILLOW COMMUNITIES AND THEIR DIVERSITY IN THE POGÓRZE STRZYŻOWSKIE FOOTHILLS (WESTERN CARPATHIANS)
}

\author{
KRYSTYNA TOWPASZ ${ }^{1}$, ALINA STACHURSKA-SWAKOŃ ${ }^{2}$ \\ ${ }^{1}$ Department of Plant Ecology \\ Institute of Botany, Jagiellonian University \\ ${ }^{2}$ Department of Plant Taxonomy and Phytogeography \\ Institute of Botany, Jagiellonian University \\ Kopernika 27, 31-501 Kraków, Poland \\ e-mail: alina.stachurska-swakon@uj.edu.pl
}

(Received: February 8, 2008. Accepted: May 7, 2008)

\begin{abstract}
The results of phytosociological studies on the diversity of alder-ash and willow communities in the Pogórze Strzyżowskie foothills are presented. These communities, especially Carici remotae-Fraxinetum are increasingly rare in the landscape of the Carpathians. The paper supports new data allowing better understanding of the diversity of the Carici remotae-Fraxinetum in the southern Poland. On the basis of 59 phytosociological releves two sub-associations were identified: C.r.-F. chrysosplenietosum and C. r.-F. equisetetosum maximii and the form with Alnus incana. The association Carici remotae-Fraxinetum belongs to submontane regional form and to East Carpathian variant. The significance of Caltha palustris-Chaerophyllum hirsutum community is also presented, along with the role of Carex pendula and Matteucia struthiopteris. The paper provides also documentary data on sporadic occurrence of Salicetum triandro-viminalis and Salicetum albo-fragilis communities.
\end{abstract}

KEY WORDS: Carici remotae-Fraxinetum, alder-ash communities, Carex pendula, Matteucia struthiopteris, willow communities, Pogórze Strzyżowskie foothills, Western Carpathians.

\section{INTRODUCTION}

The forest communities in the river and stream valleys of the Carpathian Foothills are increasingly rare, and those present are often affected by major transformations reflecting the alterations in spatial land management. It is necessary to document, on a current basis, those small patches of communities which naturally have not occupied large surfaces.

Todate, the body of publications covering the carr communities of Poland, particularly those pertaining to the Carpathian Foothills, has been fairly limited. Within the carrs included in the class Querco-Fagetea, the current records in the Carpathian Foothills are as follows: Carici remotae-Fraxinetum, Caltho-Alnetum, Alnetum incanae and a transitional community between Circaeo-Alnetum and Carici remotae-Fraxinetum, as well as Salicetum triandroviminalis and Salicetum albo-fragilis from the Salicetea purpurae class (Czylok and Rahmonov 2007; Dzwonko 1986; Matuszkiewicz 2001; Matuszkiewicz 1976; Medwecka-Kornaś 1959, 1976; Medwecka-Kornaś et al. 1987; Różański et al. 1993; Stachurska 1998; Towpasz 1990).
The published releves of the association Carici remotaeFraxinetum characteristic of the Carpathian Foothills, are contained in the studies by Różański et al. (1993 - 1 releve from the Pogórze Wielickie foothills), Czylok and Rahmonov (2007 - 19 releves from the Pogórze Śląskie foothills), Matuszkiewicz (1976 - 28 releves from the Pogórze Dynowskie foothills). The first two releves of this association, authored by Grodzińska and Pancer-Kotejowa (1965), were undertaken in the Bukowica range of the Beskid Niski Mts.

Documenting these localities is of paramount importance due to the ongoing destruction of these communities, both directly and indirectly, through the alterations in species composition resulting from the expansion of invasive taxa. The low number of published phytosociological materials also prevents the determination of the variability of these communities throughout Poland. The aim of this study is to provide materials for a further broader discussion on the nature of carr communities in the Carpathian Foothills, and particularly of the association Carici remotae-Fraxinetum Koch 1926. 


\section{STUDY AREA}

The Pogórze Strzyżowskie foothills are situated in the eastern part of the Western Carpathians. To the west, along the Wisłoka River, they border the Pogórze Ciężkowickie foothills while to the east, where they follow the course of the Wisłok River - the Pogórze Dynowskie foothills. The northern border is formed by the Płaskowyż Kolbuszowski plateaux (the Kotlina Sandomierska basin), whereas to the south, the area borders the Doły Jasielsko-Sanockie depressions (Fig. 1). The size of the area so denoted is ca. 1120 $\mathrm{km}^{2}$.

The broad humps which predominate in the land relief are of an upland character, with elevations not exceeding 350-450 $\mathrm{m}$ a.s.1., separated by deep river valleys. In the southern part, there are also some ranges with steep, often edge-like slopes, reaching up to $540 \mathrm{~m}$ a.s.1.

In terms of geological structure, the area is comprised of the flysh deposits, mainly from the Createceous and Paleogene periods. They are sandstones, conglomerates and shales which form two nappes: the Skolska nappe and the Śląska nappe. They are overlain by the Quaternary deposits: alluvia, loess, silty clays, as well as diluvia and colluvia. The deposits mentioned differ from each other in the content of the calcium carbonate fraction, and in the degree of lithification.

The soils in the northern part of the Pogórze Strzyżowskie foothills originated predominantly from loess and loess-like deposits. The dusty soils are utilised mainly as cultivated soils. In the southern part of the area, soil erosion (predominately sandstone and shales) is increasing. The summits or hilltop plateaux are occupied by skeletal soils. In terms of the genetic classification of soils, the most widespread type is brown soils, whilst rendzina and pararendzina soils are found on the slopes of river valleys whereas the bottoms of the river and stream valleys are comprised of the alluvial, deluvial and ground-gley soils.
The study area is situated in a moderately warm climatic altitudinal zone, and its climate is a sub-mountain type.

At present, in the landscape of the Pogórze Strzyżowskie foothills, on the rolling slopes and plateaux, cultivated hills predominate, occupying ca. $70 \%$ of the area, with the steeper gradients are often wooded (15\% of the area). Meadows are less predominant and occur chiefly in river valleys and in built-up areas.

More details pertaining to the area are given in Towpasz (1990).

\section{MATERIAL AND METHODS}

The studies followed the generally accepted principles of the Braun-Blanquet method (1964). The phytosociological releves were obtained in the largest possible number of patches in the various carr communities in the Pogórze Strzyżowskie foothills, in a way that reflected the considerable variety of these woods. The materials presented have been obtained predominately in the years 1978-1991. Supplementary studies were added in 2007. A total of 59 phytosociological releves provided the basis for analysis, and which underwent numerical analysis through use of the UPGMA method (SYN-TAX 2000 - Podani 2001). The releves were analysed twice: first taking into account the presence of the species, and second concerning their abundance. In the first case, the Jaccard coefficient was used, whilst in the second - the Ružicka's formula was applied. Comparing the results of these two methods permitted the allocation of the releves into groups, which were then subjected to a thorough floristic analysis (Fig. 2).

In the identification of syntaxonomic affiliations of groups of releves distinguished in the analysis of the outcome of the classification, used the publications e.g. by: W. Matuszkiewicz (1976, 2001), J.M. Matuszkiewicz (2001), and Medwecka-Kornaś (1972).

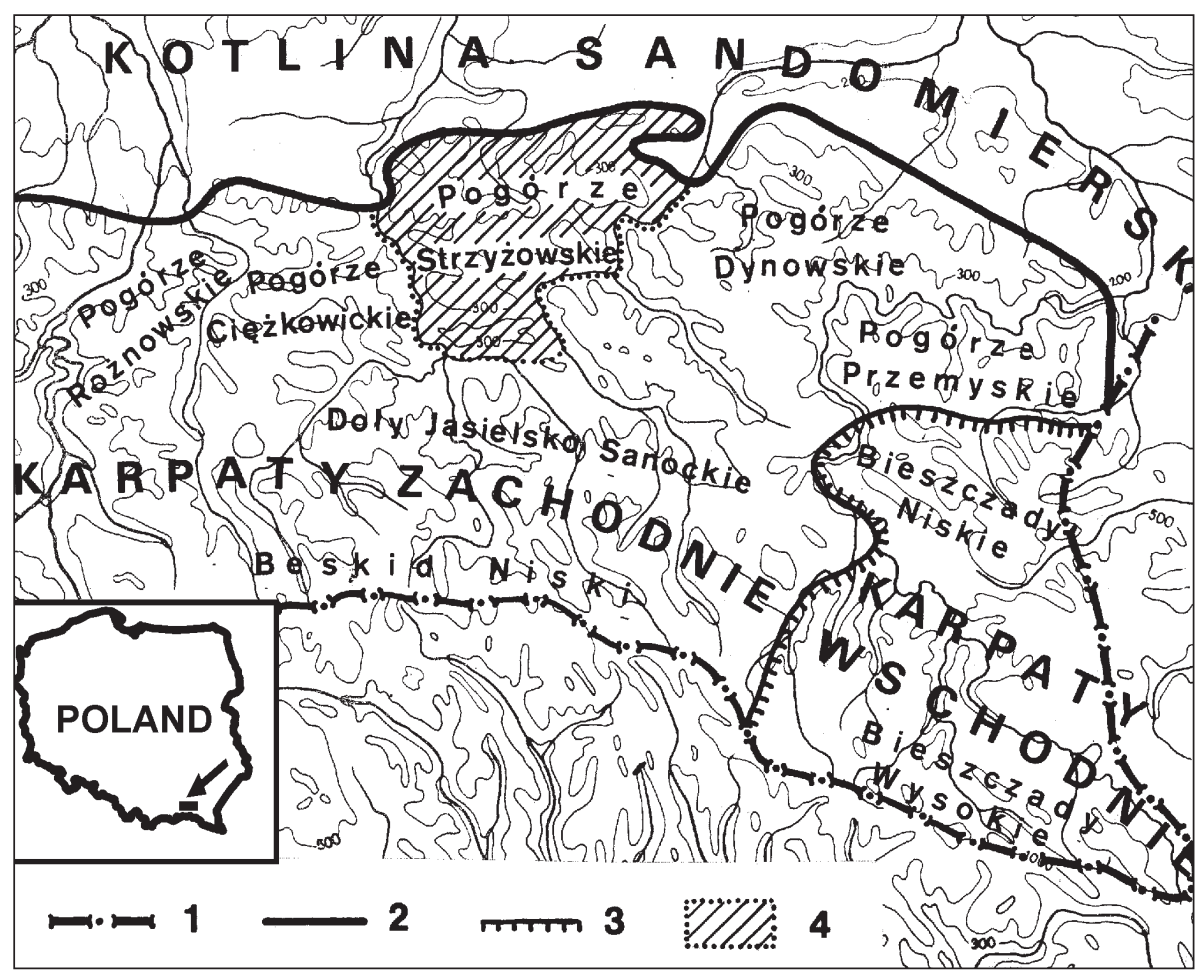

Fig. 1. Localization of the study area against the regional division of the eastern part of the Polish Carpathians (after Kondracki 1978): 1 - state boundary, the northern limits of the Carpathians, 3 - boundary between the Western and Eastern Carpathians, 4 - the area investigated. 


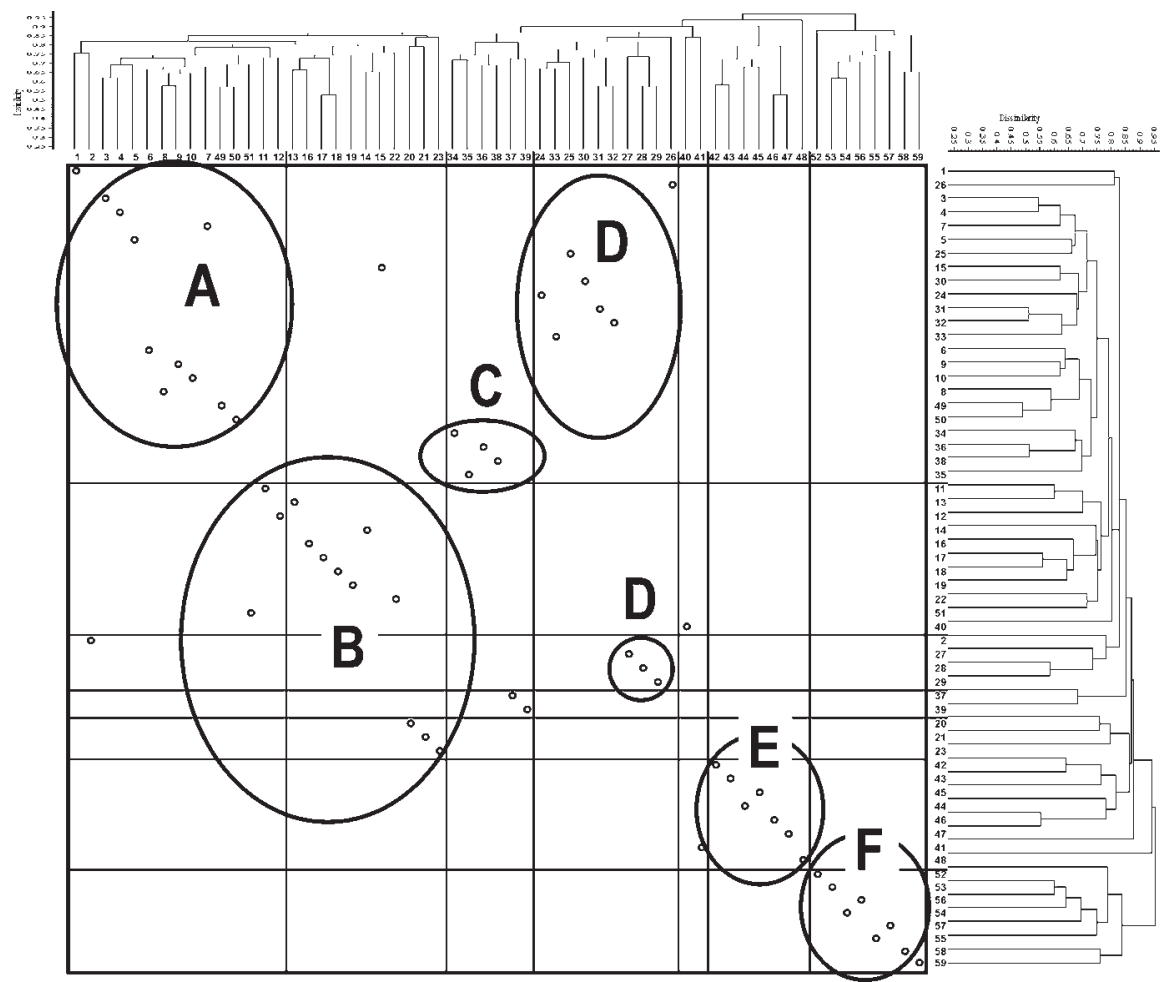

Fig. 2. Dendrogram based on the numerical classification. Dendrogram I constructed with species abundance taken into account. Dendrogram II made on the basis of species presence/absence. Explanations of the groups name see in the text.
The nomenclature of vascular plants follows Mirek et al. (2002).

\section{RESULTS AND DISCUSSION}

The carr communities in the Pogórze Strzyżowskie foothills occupy small strips along streams, flowing in narrow $\mathrm{V}$-shaped valleys and on low terraces around meandering minor streams as well as on low or high terraces in the valleys of major rivers.

The results of numerical classification indicate the presence of several communities (Fig. 2): submontane carr Carici remotae-Fraxinetum (differentiated into two subassociations) and its degraded form with the presence of $\mathrm{Al}$ nus incana (class Querco-Fagetea), the tall-herb community Caltha palustris-Chaerophyllum hirsutum (class Molinio-Arrhenatheretea), as well as willow-poplar carrs represented by the shrub association Salicetum triandro-viminalis and arborescent willow carr Salicetum albo-fragilis (class Salicetea purpureae).

The submontane carr Carici remotae-Fraxinetum occurs usually in small strips along minor stream valleys. The specific physiognomy of this association is connected with the presence, in the ground vegetation, of tall and dense tussocks of Carex pendula, a species considered to be a characteristic of this association. The patches of this association also usually have: Carex remota, Equisetum telmateia, and Rumex sanguineus. The tree layer is formed by: Alnus glutinosa and Fraxinus excelsior, whereas the shrub layer is usually only poorly developed.

Among the releves from the study area, three groups stand out: Group A (Fig. 2, Table 1: releves 1-13) is characterised by the domination of Alnus glutinosa in the tree stand. In the herb layer, Carex remota is constantly present, and often Carex pendula, Veronica montana and Salvia glutinosa are also present. The species characteristic of the order Fagetalia: Dentaria glandulosa, Galeobdolon luteum, Pulmonaria obscura and Ranunculus lanuginosus are also common. A group of these releves represents a typical subassociation Carici remotae-Fraxinetum chrysosplenietosum. The patches from where the releves were obtained, were primarily located in broadened parts of valleys, in flat but not very humid places in moist oak-hornbeam forest Tilio-Carpinetum stachyetosum; hence, the large proportion of species of Fagetalia order.

Group B (Fig. 2, Table 1: releves 14-26) is characterised by the co-occurrence of Alnus glutinosa and Fraxinus excelsior (in either the a or b layer). A typical feature is the occurrence of Equisetum telmateia, Valeriana simplicifolia in the forest herb vegetation, as well as the greater occurrence of Stellaria nemorum. As the patches studied through releves are often situated in the mouths of stream valleys, in very wet places, an increased proportion of species associated with such habitats, such as: Cardamine amara, Solanum dulcamara, Myosotis palustris, Filipendula ulmaria, Angelica sylvestris and Cirsium rivulare (e.g. releves 15, 16, and 19) has been found. This group represent the subassociation Carici remotae-Fraxinetum equisetetosum maximii. On the basis of currently available material, the authors of this paper are not inclined to rank this as an association, as proposed by Oberdorfer (1992). Slightly different characteristics are shown by releves 21 and 24. Because of the significant proportion of swamp species, of the class Phragmitetea, e.g. Berula erecta, Carex pseudocyperus, Glyceria maxima, and Scrophularia umbrosa, correspond more with a lowland association Fraxino-Alnetum.

Group C encompasses very narrow strips on the banks of streams, usually in their source stages. It is marked by the absence of Alnus glutinosa in the tree layer (Fig. 2, Table 1: releves 27-34), whereas Fraxinus excelsior and Fagus sylvatica occur on these sites. Also present are all species characteristic of the association Carici remotae-Fraxinetum. Also emphasized should be the proportion of Carex 


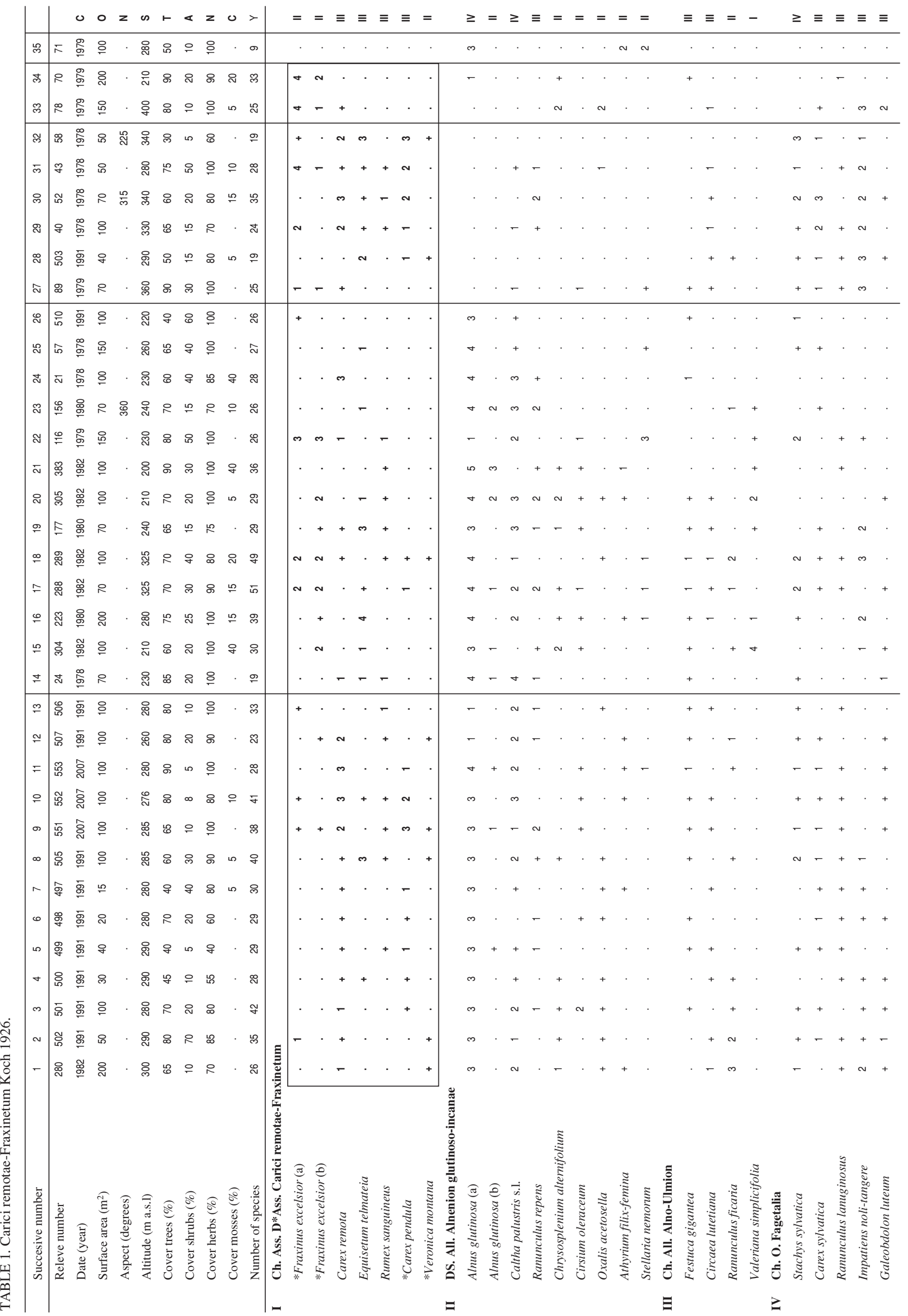



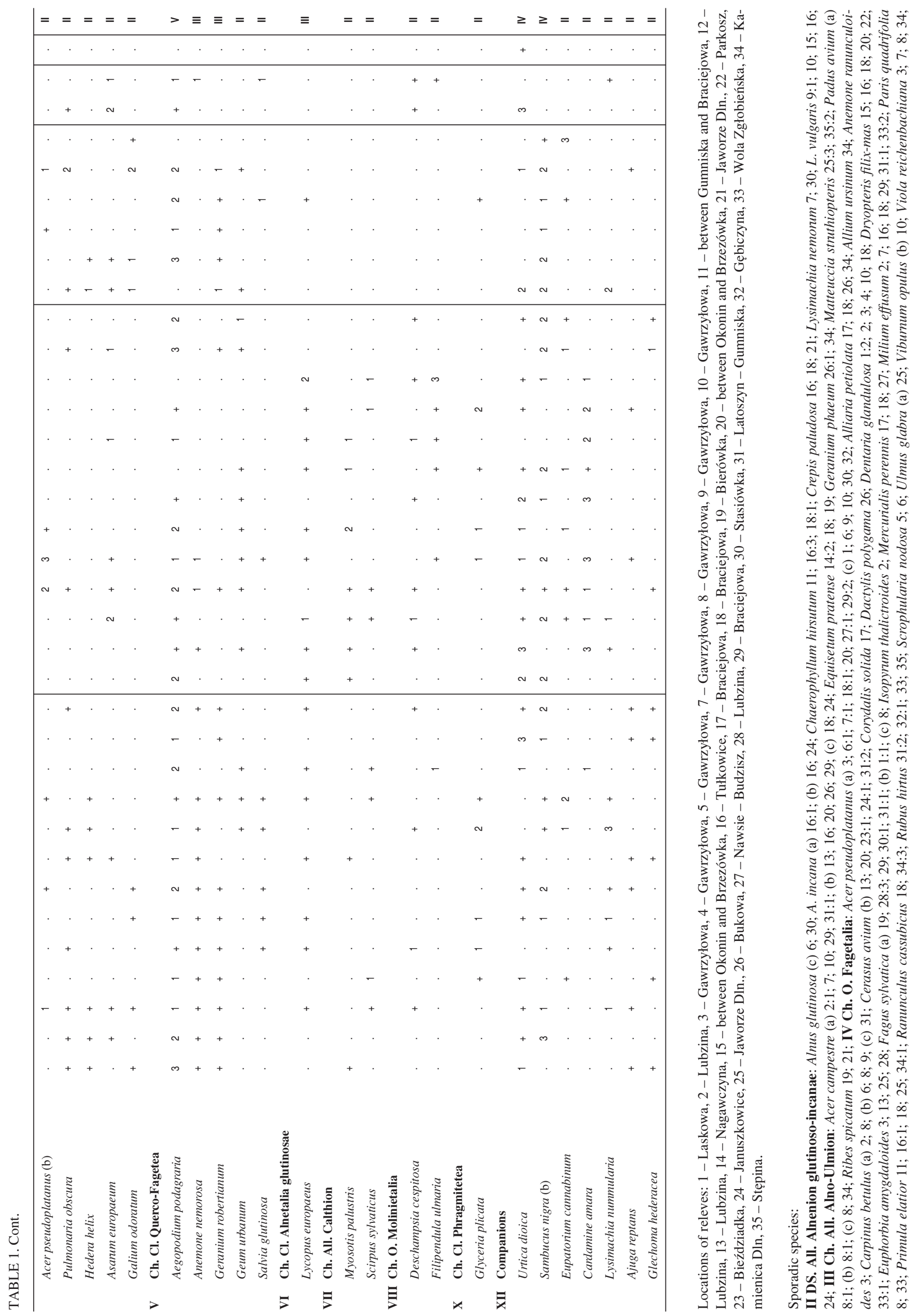
TABLE 1. Sporadic species - cont.

V Ch. Cl. Querco-Fagetea: Brachypodium sylvaticum 3; 22; 25:1; 33:1; Campanula trachelium 30; 34; Cornus sanguinea (b) 2; 16:1; 21; 25; 31; (c) 27; Corylus avellana (b) 17; 18:1; 22; 33; Crataegus monogyna (b) 26; Equisetum sylvaticum 33; Euonymus europaea (b) 2; 4; 11; (c) 3; 10; 18; 27; 33; E. verrucosa (b) 5; Fraxinus excelsior (c) 9; 15; 29:1; Melica nutans 3; Poa nemoralis 25; 35; Polygonatum multiflorum 18; 33; 34; Ranunculus auricomus 15; VI Ch. Cl. Alnetea glutinosae: Carex elongata 21:1; Solanum dulcamara 21:2; 22:1; 24; VII Ch. All. Calthion: Cirsium rivulare 15; 16; 19; Juncus effusus 10; 30; 32:1; VIII Ch. O. Molinietalia: Cirsium palustre 30; Equisetum palustre 10; 22:1; Galium uliginosum 21; Lychnis flos-cuculi 15; 17; Lythrum salicaria 6; Valeriana officinalis 24; IX Ch. Cl. Molinio-Arrhenatheretea: Angelica sylvestris 14; 15; 19; 21; 24:1; Dactylis glomerata 17; Geranium pratense 16; Poa trivialis 8; 12; 13; 14:1; 17:1; 33; Prunella vulgaris 30:2; Rumex acetosa 23; Taraxacum officinale 3; 7; 23; 26; X Ch. Cl. Phragmitetea: Berula erecta 21; 24; Carex gracilis 21:4; C. pseudocyperus 24:2; Glyceria maxima 21; Scrophularia umbrosa 21; Veronica anagalis-aquatica 8; 24:1; Veronica beccabunga 5; 9:1; 10; 17; 23; 30; XI Ch. Cl. Salicetea purpurae: Calystegia sepium 24:2; Humulus lupulus 10; Salix fragilis (a) 5; 11:1; S. alba (a) 13:1; 17:1; (b) 13; XII Companions: Abies alba (b) 15:1; 20; 35; (c) 29; Aesculus hippocastanum (a) 13:3; (b) 13; (c) 13:1; Agrimonia eupatoria 34:1; Anthemis arvensis 26; Anthriscus sylvestris 34:2; Arctium minus 17; 29; 34; Betula pendula (b) 23; Carex brizoides 35:5; Cerastium arvense 16; C. macrocarpum 17; 30; C. sylvaticum $13 ; 22 ; 25: 1 ;$ Chaerophyllum aromaticum $8 ; 13 ; 25: 1 ; 34: 1 ;$ Cruciata glabra 24; Dactylorhiza majalis $23 ;$ Dryopteris carthusiana $2 ; 21: 1 ; 23$; Elymus caninus $34 ;$ Epilobium montanum $30 ; 32 ;$ Equisetum arvense $3: 1 ; 4: 1 ; 17 ; 23 ; 24: 2 ; 25 ;$ E. fluviatile $21: 1 ;$ Fragaria vesca 7 ; 25:1; Frangula alnus (b) 2:1; 9; 11; 12:1; 21:1; 22:1; 24:3; Galeopsis pubescens 2; Galium aparine 11; 13:1; 15:2; 20; 21; 33:1; 34; Hypericum hirsutum 30; H. maculatum 16; H. perforatum 32; Impatiens parviflora $8 ; 9 ; 10 ;$ Lamium maculatum 26; Lapsana communis 34; Mentha aquatica 3; 4; 5; 8; 21; 23:1; M. longifolia 12:1; 17; 25; Moehringia trinervia 7; 17; 18; Mycelis muralis $2 ; 7 ; 10 ; 17 ; 30 ; 32 ;$ Petasites albus $11 ; 25: 1 ;$ P. hybridus 21:1; 26:1; Plantago major 30; Poa annua 17; 30; Polygonum hydropiper 18; Populus tremula (a) 2; Ribes uva-crispa 26; Rosa canina 4; Rubus caesius 5; 9; 26:1; 2; R. idaeus 3; 14:1; 16; 18; 20; 24:1; R. nessensis 4; Rumex obtusifolius 4; 5; 7; 18; 19:1; 32; Salix caprea (b) 6; Sambucus nigra (c) 2; 28; 34; S. racemosa (b) 19:2; Senecio fluviatilis 26; S. nemorensis 3; 30:1; 34; Solidago gigantea 9; 21:1; 23; 34; Sorbus aucuparia (b) 20; 24; Stachys alpina 30; Stellaria alsine 17; Stellaria neglecta 8; 12; 13:3; Tussilago farfara 4; 5:1; 6:1; 8; 17; 26; 30; Viola odorata 26.

pendula which occurs in this group, even with the third level of abundance. Apart from this, the species characteristic of the Fagetalia order appear in the herb layer, particularly Impatiens noli-tangere, Stachys sylvatica, Carex sylvatica and Galium odoratum, that migrate there from the patches of oak-hornbeam forest Tilio-Carpinetum, situated in higher elevations. The species of wet habitats are almost completely absent.

It is interesting to note the presence of Matteucia struthiopteris, a protected species, rare in Poland and recorded in two releves (Table 1: releves 25 and 35). This fern has been found in the Pogórze Strzyżowskie foothills in a patch of the association Carici remotae-Fraxinetum equisetetosum maximii (Table 1, releve 25), although J.M. Matuszkiewicz (2001) associates it with Alnetum incanae. The other releve (35), with limited species composition, without the species characteristic of the association, has a submontane carr with Alnus glutinosa, and with the domination of Carex brizoides.

Comparing the presented phytociological data obtained from submontane carr with a review work, summing up the data on forest communities in the Carpathians (Dzwonko 1986), allows classification of this carr as a form of the association Carici remotae-Fraxinetum from lower mountain sites. In Dzwonko's paper, this form has been described on the basis of 11 releves from the Pogórze Dynowskie foothills, which borders the eastern limit of the Pogórze Strzyżowskie foothills. Additionally, the submontane carr from the Pogórze Strzyżowskie foothills, should be classified as an East-Carpathian variant, in spite of the fact that releves of the association concerned did not contain the East-Carpathian species Aposeris foetida, which has been reported to distinguish this variant (J.M. Matuszkiewicz 2001). This taxon is, however, found there in patches within other forest associations (particularly in Tilio-Carpinetum stachyetosum), often situated close to Carici remotae-Fraxinetum. Classifying this association as an East-Carpathian variant is further supported by the presence of another species regarded as an East-Carpathian type; namely Cerastium sylvaticum (Towpasz 1990).

According to J.M. Matuszkiewicz (2001), Carex strigosa - characteristic of the lowland Carici remotae-Fraxinetum, is a rare taxon in Poland, and as such has been placed in the „The Polish Red Book of Plants” (Baryła 1993, Baryła, Czylok 2001). The studies, also undertaken in the Carpathian Foothills, revealed that the species has some localities there, albeit not many (Zając and Zając 2001; Zając et al. 2006). Czylok and Rahmonov (2007), in the paper devoted to the characteristics of the submontane carr of the Pogórze Śląskie foothills, report, that the species occurs in

Locations of releves: 1 - Gawrzyłowa, 2 - Jaworze Dln., 3 - Gawrzyłowa, 4 - Babica, 5 - Stobierna, 6 - between Stobierna and Zawada, 7 - Braciejowa, 8 - Gawrzyłowa, 9 - Gawrzyłowa, 10 - Okonin.

Sporadic species:

II DS. All. Alnenion glutinoso-incanae: Alnus incana (c) 5; Athyrium filix-femina 1; Chaerophyllum hirsutum 7:3; Lysimachia nemorum 2:2; Stellaria nemorum 4:1; 7:3; III Ch. All. Alno-Ulmion: Acer campestre (c) 5; 6; Equisetum pratense 2:3; Padus avium (a) 1; (c) 10:1; IV Ch. O. Fagetalia: Acer pseudoplatanus (c) 9; Alliaria petiolata 4; 7; Anemone ranunculoides $1 ; 2$; Carpinus betulus (a) 1 ; (c) 5 ; Corydalis solida 1:2; 7; Dryopteris filix-mas 10 ; Equisetum sylvaticum 7:1; Euphorbia amygdaloides 5; 6:1; Galium odoratum 1; Hedera helix 9; 10; Paris quadrifolia 1; 8; Primula elatior 7; Ranunculus cassubicus 1; 2; Rubus hirtus 1; 2; 1; Stellaria holostea 2:1; 10; Symphytum tuberosum 2; Viburnum opulus (b) 4; 8; V Ch. Cl. Querco-Fagetea: Brachypodium sylvaticum 2:1; Campanula trachelium 5; Corylus avellana (b) 7:2; 9; Crataegus sp.(c) 1; Euonymus verrucosa (c) 6; 10; Melica nutans 1; Moehringia trinervia 4; 7; VI Ch. Cl. Molinio-Arrhenatheretea: Achillea millefolium 5; 6; Dactylis glomerata 4:1; 5; Galium mollugo 5; 6; Heracleum sphondylium 5; Myosotis palustris 3:2; 7; Poa trivialis 4; 5:1; Rumex acetosa 5; VII Ch. CI. Salicetea purpurae: Calystegia sepium 5; Humulus lupulus 5; Salix alba (a) 5; S. fragilis (a) 5:2; 6:2; (b) 6; S. purpurea (b) 5; VIII Companions: Abies alba (c) 10; Ajuga reptans 2; 7; Anthriscus sylvestris 5; Arctium minus 5; 6; Bilderdykia dumetorum 2; Carex brizoides 1; Cerastium macrocarpum 5; Equisetum arvense 2:1; 9; Eupatorium cannabinum 5; Fragaria vesca 2:1; 4; Galium aparine 5:1; Hypericum montanum 9; Ligustrum vulgare (b) 4; (c) 2; Lysimachia nummularia 4; 5; Maianthemum bifolium 2:1; Mentha longifolia 5; Mycelis muralis 8; Populus nigra (a) 6; P. tremula (a) 9; Potentilla reptans 5; Pyrus communis (b) 2; Quercus robur (a) 10; Rubus nessensis 5; Rumex obtusifolius 3; 5; Sambucus nigra (c) 3; 10:1; Senecio nemorensis 8; 9; Stellaria neglecta 5:1; 6:2; Telekia speciosa 2; Veronica chamaedrys 5; V. hederifolia 5; Vicia dumetorum 8; Vincetoxicum hirundinaria 2:1. 
TABLE 2. Carici remotae-Fraxinetum form with Alnus incana.

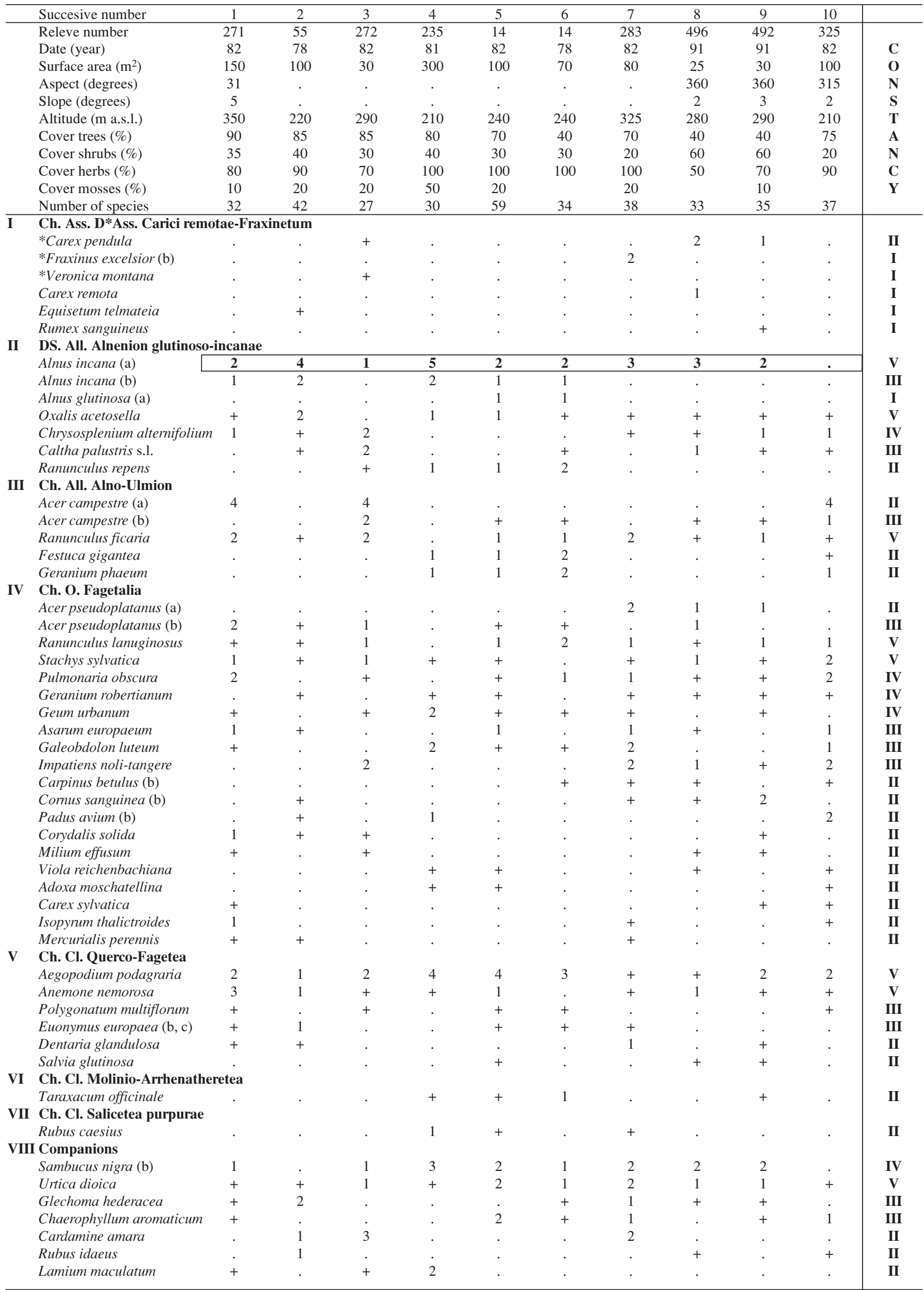


the area with considerable constancy. Carex strigosa also grows in the carr communities of the western part of the Carpathian Foothills (Stachurska-Swakoń unpbl). Thin-spiked Wood-sedge have also been found at the eastern border of the Pogórze Strzyżowskie foothills - in the locality of Przedmieście Czudeckie (Baryła 1993, Baryła and Czylok 2001) and Brzostek (Towpasz unpbl). Despite a thorough search, the authors of this paper have not been able to locate the species in the patches of the association concerned in this study.

This study has confirmed the role of Carex pendula, as a species characteristic of the association Carici remotaeFraxinetum in the Carpathian Foothills. According to J.M. Matuszkiewicz (2001), this species is, in exceptional cases, also found outside the Carpathians in the Sudeten variant of the association.

The releves shown in Table 2 (Fig. 2, group D) have a hazy syntaxonomic status. The carr communities from which these releves were obtained developed principally in the flat valleys of minor rivers where they occupy in narrow strips along their banks. The species which forms the tree stand is Alnus incana. Acer campestre co-occurs both within the tree layer (where it is rarer), and the shrub-layer. In the herb layer, several releves also recorded the presence of the species characteristic of Carici remotae-Fraxinetum, which could indicate a degraded form of the association. This idea is further supported by significant proportions of nitrophilous species: Sambucus nigra (in the shrub layer, releves 1 to 3), and Urtica dioica. The following can more frequently be found on the forest floor: Geranium robertianum, Geum urbanum and Aegopodium podagraria. Carici remotae-Fraxinetum with Alnus incana dominating in tree stands, were described in the Bukowica range in the Beskid Niski Mts. by Grodzińska and Pancer-Kotejowa (1965). Nitrophilous species, such as Sambucus nigra or Urtica dioica are, however, absent. Some of the releves (e.g. 5 and 6) exhibit the willow Salix fragilis in the tree stands and the forest floor vegetation layer with a major presence of species from the Fagetalia order, correspond to Alnetum incanae, known from the Ciężkowice foothill region (Medwecka-Kornaś 1976).

The tall-herb community Caltha palustris-Chaerophyllum hirsutum (Table 3) develops on flat valley bottoms. It takes advantage of the 'side' shade offered by neighbouring trees or it is deprived of any shade at all. Under numerical classifications, this community forms a separate group E (Fig. 2). All patches are distinguished by the occurrence of two species: Caltha palustris s.l. and Chaerophyllum hirsutum, as well as by the presence of Filipendula ulmaria and Cardamine amara. Also typical, is the presence of the species of wet habitats characteristic of the suballiance Alnenion glutinoso-incanae: Cirsium oleraceum, Crepis paludosa and Stellaria nemorum. In the case of patches with Alnus glutinosa and Fraxinus excelsior occurring in the tree stands, also noted is the presence of species characteristic from the Fagetalia order (Table 3 releves 1-3): Dentaria glandulosa, Impatiens noli-tangere, Primula elatior, and Stachys sylvatica, and of the Querco-Fagetea class; namely Anemone nemorosa. In the treeless places there are higher proportions of meadow species from the Molinio-Arrhenatheretea class: Cirsium rivulare (of the Calthion alliance),
Dactylis glomerata, Poa trivialis, and Rumex acetosa (Table 3, releves 4-6). Occasionally (releve 4), the occurrence of species characteristic of the associations Carici remotaeFraxinetum: Equisetum telmateia and Rumex sanguineus have been noted.

The occurrence of this community has been confirmed in the Pogórze Wielickie foothills, where (similarly as in the study area) it occupies only small spaces (Medwecka-Kornaś et al. 1987; Trzcińska-Tacik and Stachurska-Swakoń 2001). Minute floristic differences, compared with other forest phytocoenoses representing the alliance AlnoUlmion, result in difficulties in distinguishing these patches as a unit worthy of the rank of association (Medwecka-Kornaś 1987). The physiognomy of this association resembles the forest spring bogs described in the lower montane zone in the Gorce Mts. (Kornaś and Medwecka-Kornaś 1967).

The willow-poplar carr communities Salici-Populetum which are more common in the lowland part of Poland, are fairly rare within the Carpathian Foothills. Their distribution is principally associated with the valleys of major rivers or shorelines of large bodies of water. In the study area, the shrub association Salicetum triandro-viminalis are found, as well as the arborescent communities representing fragments of riparian willow association Salicetum albofragilis (Table 4, Fig. 2 - group F). The latter is commonly regarded to be a subsequent stage in the succession of riparian willow-poplar carrs. The releves representing the willow-poplar carrs were obtained from the Wisłoka river valley. In the past, such communities also occurred along the Wisłok river valley, indicated by single remaining specimens of willows, both in tree and shrub forms.

The association Salicetum triandro-viminalis is formed principally by three species of willows: Salix triandra, Salix purpurea, and Salix viminalis. In the forest herb vegetation, they are accompanied by taxa characteristic of the Salicion albae alliance: Calystegia sepium, Rubus caesius, Urtica doica, and Phalaris arundinacea. However, species characteristic of the carr communities of the Alno-Ulmion alliance, wet meadows of the Molinio-Arrhenatheretea class, rushes of the Phragmitetea class, and the communities of terophytes from the Bidentetea class, occur only sporadically. A characteristic feature of the patches of this association is the abundant occurrence of a holoagriophyte, Solidago gigantea, a North-American species, which is rapidly changing the characteristics of the willow-poplar carr. Another kenophyte, Helianthus tuberosus, also abundant in riparian willow shrubs, has similar characteristics. Other kenophytes, such as Echinocystis lobata and Impatiens parviflora, are also present, albeit less frequently. The occurrence and massive colonization by kenophytes, is related to the destruction of these communities by Man and with the instability of their habitats caused, inter alia, by periodic flooding. The willow-poplar carr communities are distinct for their limited species communities - the releves have recorded a mere 12-14 species (Table 4, releves 4 and 5).

Similarly, the riparian willow carr Salicetum albo-fragilis, is now sporadically found along the Wisłoka river, where it develops only as fragments. It is represented by only three releves (Table 4, releves 6-8). A characteristic feature of these carrs is the occurrence of willows: Salix alba and S. fragilis, as well as of the black poplars Populus 
TABLE 3. Caltha palustris-Chaerophyllum hirsutum community.

\begin{tabular}{|c|c|c|c|c|c|c|c|}
\hline Succesive number & 1 & 2 & 3 & 4 & 5 & 6 & \\
\hline Releve number & 68 & 284 & 108 & 287 & 286 & 285 & \\
\hline Date (year) & 79 & 82 & 79 & 82 & 82 & 82 & C \\
\hline Surface area $\left(\mathrm{m}^{2}\right)$ & 100 & 200 & 50 & 100 & 100 & 100 & $\mathbf{O}$ \\
\hline Aspect (degrees) & . & . & . & 135 & . & . & $\mathbf{N}$ \\
\hline Slope (degrees) & . & . & . & 2 & . & . & $\mathbf{S}$ \\
\hline Altitude (m a.s.1.) & 300 & 325 & 440 & 325 & 325 & 325 & $\mathbf{T}$ \\
\hline Cover trees $(\%)$ & 65 & 75 & 55 & . & . & . & $\mathbf{A}$ \\
\hline Cover shrubs $(\%)$ & 30 & 40 & 5 & . & . & . & $\mathbf{N}$ \\
\hline Cover herbs $(\%)$ & 100 & 100 & 100 & 100 & 100 & 100 & C \\
\hline Cover mosses $(\%)$ & 15 & 20 & . & 50 & 5 & 15 & $\mathbf{Y}$ \\
\hline Number of species & 22 & 31 & 14 & 18 & 32 & 23 & \\
\hline \multicolumn{8}{|l|}{ I D. com. } \\
\hline Caltha palustris s.l. & 2 & 2 & 2 & 3 & + & + & $\mathbf{V}$ \\
\hline Chaerophyllum hirsutum & 4 & 4 & 5 & 4 & 4 & 4 & $\mathbf{V}$ \\
\hline \multicolumn{8}{|c|}{ II DS. All. Alnenion glutinoso-incanae } \\
\hline Alnus glutinosa (a) & 2 & 4 & 3 & . & . & . & III \\
\hline Alnus glutinosa (b) & . & . & + & . & . & . & $\mathbf{I}$ \\
\hline Fraxinus excelsior (a) & 3 & 2 & . & . & . & . & II \\
\hline Fraxinus excelsior (b) & 2 & 2 & . & 1 & . & . & III \\
\hline Cirsium oleraceum & 2 & 1 & . & 1 & 1 & 2 & $\mathbf{V}$ \\
\hline Stellaria nemorum & . & . & 2 & 2 & 3 & 2 & IV \\
\hline Crepis paludosa & 1 & 1 & + & . & + & . & IV \\
\hline Ranunculus repens & . & + & 1 & . & + & + & IV \\
\hline Equisetum telmateia & 1 & + & . & 2 & . & . & III \\
\hline Chrysosplenium alternifolium & . & . & . & 1 & . & . & $\mathbf{I}$ \\
\hline Rumex sanguineus & . & . & . & + & . & . & $\mathbf{I}$ \\
\hline \multicolumn{8}{|l|}{ III Ch. All. Alno-Ulmion } \\
\hline Ficaria verna & . & 1 & . & + & . & . & II \\
\hline \multicolumn{8}{|l|}{ IV Ch. O. Fagetalia } \\
\hline Impatiens noli-tangere & . & 2 & 1 & 2 & . & . & III \\
\hline Primula elatior & + & + & . & . & 1 & + & IV \\
\hline Dentaria glandulosa & + & + & . & . & . & . & II \\
\hline Stachys sylvatica & + & + & . & . & . & . & II \\
\hline \multicolumn{8}{|l|}{ V Ch. Cl. Querco-Fagetea } \\
\hline Anemone nemorosa & . & + & . & . & 1 & + & III \\
\hline Euonymus europaea (b) & 1 & 1 & . & . & . & . & II \\
\hline Aegopodium podagraria & . & . & . & + & . & + & II \\
\hline \multicolumn{8}{|l|}{ VII Ch. All. Calthion } \\
\hline Myosotis palustris & . & + & 1 & . & + & + & IV \\
\hline Cirsium rivulare & . & . & . & . & 1 & 1 & II \\
\hline \multicolumn{8}{|l|}{ VIII Ch. O. Molinietalia } \\
\hline Filipendula ulmaria & 1 & 1 & . & 1 & 1 & + & $\mathbf{V}$ \\
\hline Equisetum palustre & + & + & . & . & . & . & II \\
\hline \multicolumn{8}{|c|}{ IX Ch. Cl. Molinio-Arrhenatheretea } \\
\hline Dactylis glomerata & . & . & . & . & 2 & 3 & II \\
\hline Poa trivialis & . & . & . & . & 1 & + & II \\
\hline Rumex acetosa & . & . & . & . & 1 & + & II \\
\hline \multicolumn{8}{|l|}{ XII Companions } \\
\hline Cardamine amara & 2 & 3 & 1 & 3 & + & . & $\mathbf{V}$ \\
\hline Urtica dioica & . & + & 2 & 1 & 1 & 1 & $\mathbf{V}$ \\
\hline Lysimachia nummularia & . & + & + & . & . & + & III \\
\hline Eupatorium cannabinum & + & . & . & + & . & . & II \\
\hline Ajuga reptans & . & . & . & . & + & + & II \\
\hline Equisetum pratense & . & . & + & . & + & . & II \\
\hline Veronica chamaedrys & . & . & . & . & + & + & II \\
\hline Alchemilla xanthochlora & . & . & . & . & 1 & + & II \\
\hline
\end{tabular}

Locations of releves: 1 - Czudec, 2 - Braciejowa, 3 - Kamienica Grn. - Klonowa Góra, 4 - Braciejowa, 5 - Braciejowa, 6 - Braciejowa.

Sporadic species:

II DS. All. Alnenion glutinoso-incanae: Athyrium filix-femina 2; Lysimachia vulgaris 1; III Ch. All. Alno-Ulmion: Acer campestre (b) 1; Circaea lutetiana 2; IV Ch. O. Fagetalia: Acer pseudoplatanus (c) 2; Asarum europaeum 2; Carex sylvatica 4; Equisetum sylvaticum 5; Mercurialis perennis 1; Isopyrum thalictroides 1:3; Paris quadrifolia 1; Pulmonaria obscura 2; Ranunculus cassubicus 2; R. lanuginosus 6:1; V Ch. Cl. Querco-Fagetea: Fraxinus excelsior (c) 2; Euonymus europaea (c) 4; Ranunculus auricomus 5; VI Ch. Cl. Alnetalia glutinosae: Lycopus europaeus 2; VII Ch. All. Calthion: Juncus effusus 4; VIII Ch. O. Molinietalia: Deschampsia caespitosa 5; Galium uliginosum 3:1; IX Ch. Cl. Molinio-Arrhenatheretea: Achillea millefolium 5; Alopecurus pratensis 6:1; Bellis perennis 5; Taraxacum officinale 5; X Ch. Cl. Phragmitetea: Galium palustre 5; XII Companions: Alchemilla glabra 5; Anthoxanthum odoratum 5; Dryopteris dilatata 1; Equisetum arvense 1; Hypericum maculatum 5; Petasites hybridus 6; Poa remota 1 ; Rumex obtusifolius 1. 
TABLE 4. Willow associations.

\begin{tabular}{|c|c|c|c|c|c|c|c|c|c|}
\hline & Succesive number & 1 & 2 & 3 & 4 & 5 & 6 & 7 & 8 \\
\hline & Releve number & 155 & 335 & 511 & 554 & 555 & 91 & 423 & 341 \\
\hline & Date (year) & 1980 & 1982 & 1991 & 2007 & 2007 & 1979 & 1983 & 1982 \\
\hline & Surface area $\left(\mathrm{m}^{2}\right)$ & 50 & 100 & 100 & 30 & 40 & 100 & 100 & 100 \\
\hline & Cover tree layer $(\%)$ & 0 & 0 & 0 & 30 & 20 & 75 & 60 & 30 \\
\hline & Cover shrub layer $(\%)$ & 100 & 50 & 60 & 50 & 90 & 90 & 50 & 90 \\
\hline & Cover herb layer $(\%)$ & 95 & 50 & 100 & 85 & 80 & 100 & 80 & 0 \\
\hline & Number of species & 22 & 30 & 15 & 12 & 14 & 24 & 34 & 27 \\
\hline \multirow[t]{2}{*}{$\overline{\mathbf{I}}$} & \multicolumn{6}{|c|}{ Ch. Ass. Salicetum triandro-viminalis } & \multirow{3}{*}{. } & \multirow{3}{*}{2} & \multirow{3}{*}{2} \\
\hline & Salix triandra $(\mathrm{b})$ & 3 & 2 & 1 & . & . & & & \\
\hline \multirow[t]{4}{*}{ II } & \multicolumn{6}{|c|}{ Ch. Ass. Salicetum albo-fragilis } & & & \\
\hline & Salix alba (a) & . & . & . & . & + & 3 & 2 & 1 \\
\hline & Salix alba (b) & . & . & . & . & . & . & $\mathbf{1}$ & . \\
\hline & Cornus sanguinea $(\mathrm{b})$ & . & . & . & . & . & . & + & . \\
\hline \multirow[t]{2}{*}{ III } & \multicolumn{9}{|l|}{ Ch. Ass. Populetum albae } \\
\hline & Populus nigra (a) & . & . & . & . & . & + & 2 & 1 \\
\hline \multirow[t]{4}{*}{ IV } & \multicolumn{9}{|l|}{ Ch. Cl. Salicetea purpureae } \\
\hline & Salix purpurea (b) & 4 & 2 & 3 & . & . & . & 2 & 4 \\
\hline & Salix viminalis $(\mathrm{b})$ & . & 3 & . & 3 & 3 & . & 1 & . \\
\hline & Salix fragilis (a) & . & . & . & . & . & 2 & 1 & . \\
\hline \multirow[t]{6}{*}{$\mathbf{V}$} & \multicolumn{9}{|l|}{ D. All. Salicion albae } \\
\hline & Calystegia sepium & 1 & + & 1 & 1 & + & 2 & + & 2 \\
\hline & Rubus caesius & 1 & 2 & . & 2 & 2 & + & 3 & 1 \\
\hline & Urtica dioica & 1 & 2 & + & . & 2 & 2 & + & + \\
\hline & Humulus lupulus & . & + & . & + & . & + & + & . \\
\hline & Phalaris arundinacea & . & 2 & . & + & . & . & . & + \\
\hline \multirow[t]{3}{*}{ VI } & \multicolumn{9}{|l|}{ Ch. All. Alno-Ulmion } \\
\hline & Elymus caninus & . & + & . & . & . & . & 1 & . \\
\hline & Festuca gigantea & + & . & . & . & . & . & 2 & . \\
\hline VII & Ch. Cl. Querco-Fagetea & & & & & & & & \\
\hline & Aegopodium podagraria & + & + & . & . & 2 & . & 2 & 2 \\
\hline & Heracleum sphondylium & + & . & + & . & . & . & + & + \\
\hline & Cirsium oleraceum & + & . & + & . & . & . & + & . \\
\hline & Poa trivialis & . & 1 & . & . & . & + & . & + \\
\hline & Dactylis glomerata & + & . & . & . & . & . & 1 & + \\
\hline & Myosotis palustris & . & . & . & . & . & + & . & + \\
\hline & Angelica sylvestris & . & + & . & . & . & 1 & . & . \\
\hline XI & Companions: & & & & & & & & \\
\hline & Solidago gigantea & 4 & 2 & . & 3 & 1 & + & + & 2 \\
\hline & Galium aparine & + & + & 1 & . & . & + & + & + \\
\hline & Senecio fluviatilis & 1 & + & + & . & . & + & + & 2 \\
\hline & Anthriscus sylvestris & + & . & . & . & + & . & 1 & 1 \\
\hline & Chaerophyllum aromaticum & 2 & . & + & . & . & . & + & 1 \\
\hline & Helianthus tuberosus & + & . & . & 2 & 3 & . & + & . \\
\hline & Petasites hybridus & . & 1 & 4 & . & . & . & 2 & 2 \\
\hline & Ranunculus repens & . & 1 & + & . & . & 2 & 1 & . \\
\hline & Artemisia vulgaris & . & . & . & . & . & + & + & . \\
\hline & Cucubalus baccifer & . & . & + & . & . & . & + & . \\
\hline & Elymus repens & . & . & . & . & 1 & . & . & 2 \\
\hline & Galeopsis pubescens & . & . & . & . & + & + & . & . \\
\hline & Impatiens parviflora & . & . & . & + & . & 1 & . & . \\
\hline & Rumex conglomeratus & . & + & . & . & . & . & . & + \\
\hline & Rumex obtusifolius & . & . & + & . & . & 1 & . & . \\
\hline & Vicia sepium & + & . & . & . & + & . & . & . \\
\hline
\end{tabular}

Locations of releves: 1 - Kaczorowy, 2 - Jasło, 3 - Bukowa, 4 - between Jodłowa and Jaworowa, 5 - Zawadka Brzostecka, 6 - between Pilzno and Dobrków, 7 - Kowalowy, 8 - Jasło.

Sporadic species:

IV Ch. Cl. Salicetea purpureae: Salix fragilis (c) 8; VI Ch. All. Alno-Ulmion: Acer campestre (b) 1; Alnus incana (a) 6; (b) 4; Circaea lutetiana 8:1; Geranium phaeum 1; Padus avium (a) 4:1; VII Ch. Cl. Querco-Fagetea: Dactylis polygama 6:1; Euonymus europaea (b) 1 ; Scrophularia nodosa 7; Tilia cordata (b) 7; VIII Ch. Cl. Molinio-Arrhenatherea: Chrysanthemum leucanthemum 2; Deschampsia cespitosa 7; Festuca pratensis 2; Lycopus europaeus 6:1; Lysimachia vulgaris 8; Lythrum salicaria 2; Ranunculus acris 7; Taraxacum officinale 7; Vicia cracca 2; IX Ch. Cl. Bidentetea: Bidens tripartita 2; Polygonum nodosum 4; Rorippa palustris 2; X Ch. Cl. Phragmitetea: Phragmites australis 8; XI Companions: Arctium lappa 6; A. tomentosum 7; Cirsium arvense 8; Echinocystis lobata 5; Equisetum arvense 5; Eupatorium cannabinum 3; Glechoma hederacea 3:1; Matricaria perforata 2; Myosoton aquaticum 2; Potentilla anserina 8; Rorippa sylvestris 2; Rubus sp. 1; Sambucus nigra (b) 4:1; Stellaria nemorum 6:2; Tussilago farfara 2; Veronica chamaedrys 1. 
nigra s.1. In the abundant shrub layer, the willow species dominate: Salix triandra, S. purpurea, and S. fragilis. In the herb layer, there are some distinctive species from the Salicion albae alliance: Calystegia sepium, Rubus caesius, Urtica dioica, Humulus lupulus, and Phalaris arundinacea. In the same layer of these patches, the kenophytes, Solidago gigantea and Helianthus tuberosus are found. In the neighbourhood of these phytocoenoses Echinocystis lobata and Impatiens glandulifera were also growing.

Similarly rare and only fragmentarily formed willow poplar carr were also found in other parts of the Carpathian Foothills. The examplary phytosociological releves containing fragments of these communities, are from the Pogórze Wielickie foothills (Medwecka-Kornaś et al. 1987; Trzcińska-Tacik et al. 1973; Trzcińska-Tacik and StachurskaSwakon 2001). The rare occurrence of these communities is associated with their lowland characteristics, the lack of suitable habitats and extensive destruction of the existing sites, particularly during river channel improvements. The evidence of their past widespread occurrence along river valleys, is retained in the form of single individuals of old trees (willows and poplars) growing within pastures and meadows.

\section{CONCLUSIONS}

1. The presented report provides a valuable input of factual material to differentiate carr communities in the Carpathian Foothills.

2. Two subassociations: of Carici remotae-Fraxinetum were distinguished: chrysosplenietosum and equisetetosum maximii in the East-Carpathian variant and in the form known from lower altitudes. The characteristics of the degraded form of the association, with the occurrence of Alnus incana, is also provided. The occurrence of the community Caltha palustris - Chaerophyllum hirsutum in the Carpathian Foothills has also been confirmed.

3. This study underscores the role of Carex pendula as a species characteristic of the association being studied.

4. The presented releves showing the occurrence of Matteucia struthiopteris indicate the association of this species with the submontane carr Carici remotae-Fraxinetum.

5. At present, the willow-poplar carrs of the Salicetea purpurae class: shrub association Salicetum triandroviminalis and arborescent Salicetum albo-fragilis, were found developed only in fragments. These communities have been destroyed and disturbed both through the activities of Man or by periodic inundation by flood water. These are fertile and open habitats which gives kenophytes the opportunity to enter and establish themselves, and particular Solidago gigantea and Helianthus tuberosus.

\section{LITERATURE CITED}

BARYŁA J. 1993. Carex strigosa Hudson - turzyca zgrzebłowata. In: K. Zarzycki, R. Kaźmierczakowa (eds). Polska czerwona księga roślin. Paprotniki i rośliny zarodnikowe - Polish plant red data Book. Pteridophyta and spermatophyta. Instytut
Botaniki im. W. Szafera PAN, Instytut Ochrony Przyrody PAN, Kraków: 247-248. (in Polish with English summary)

BARYŁA J., CZYLOK A. 2001. Carex strigosa Hudson - turzyca zgrzebłowata. In: R. Kaźmierczakowa, K. Zarzycki (eds). Polska czerwona księga roślin. Paprotniki i rośliny zarodnikowe - Polish red data book of plants. Pteridophytes and flowering plants. Instytut Botaniki im. W. Szafera PAN, Instytut Ochrony Przyrody PAN, Kraków: 504-505. (in Polish with English summary)

BRAUN-BLANQUET J. 1964. Pflanzensoziologie. Grundzüge der Vegetationskunde. Springer Verlag. Wien, New Jork, pp. 865.

CZYLOK A., RAHMONOV O. 2007 (in press). Comments of the occurrence of submountain ash-tree marshy Carici remotae-Fraxinetum Koch 1926 on western Carpathian foothills and Silesian Upland.

DZWONKO Z. 1986. Klasyfikacja numeryczna zbiorowisk leśnych polskich Karpat. - Numerical classification of the polish Carpathian forest communities. Fragm. Flor. Geobot. 30 (2): 93-67. (in Polish with English summary)

GRODZIŃSKA K., PANCER-KOTEJOWA E. 1965. Zbiorowiska leśne Pasma Bukowicy w Beskidzie Niskim - Forest communities of the Bukowica Range (Low Beskids, Polish Western Carpathians). Fragm. Flor. Geobot. 11 (4): 563-599. (in Polish with English summary)

KONDRACKI J. 1978. Geografia fizyczna Polski. PWN, Warszawa, 463 pp. (in Polish)

KORNAŚ J., MEDWECKA-KORNAŚ A. 1967. Zespoły roślinne Gorców. I. Naturalne i na wpół naturalne zespoły nieleśne. Plant communities of the Gorce Mts. (Polish Western Carpathian). I. Natural and seminatural non-forest communities. Fragm. Flor. Geobot. 13 (3): 167-316. (in Polish with English summary)

MATUSZKIEWICZ J.M. 2001. Zespoły leśne Polski. PWN, Warszawa, 358 pp. (in Polish)

MATUSZKIEWICZ W. 1976. Przegląd fitosocjologiczny zbiorowisk leśnych Polski. Cz. 3. Lasy i zarośla łęgowe. Phytocoenosis 5 (1): 3-66.

MATUSZKIEWICZ W. 2001. Przewodnik do oznaczania zbiorowisk roślinnych Polski. Vademecum Geobotanicum 3. PWN, Warszawa, 537 pp. (in Polish).

MEDWECKA-KORNAŚ A. 1959. Zespoły leśne i zaroślowe. Szata roślinna Polski. I: 368-427. Warszawa PWN. (in Polish)

MEDWECKA-KORNAŚ A. 1972. Zespoły leśne i zaroślowe. Szata roślinna Polski. I: 385-441. Warszawa PWN. (in Polish)

MEDWECKA-KORNAŚ A. 1976. Szata roślinna Białej Dunajcowej - Vegetation of the Biała river-basin. Studia Ośr. Dok. Fizjogr. V: 137-167. (in Polish with English summary)

MEDWECKA-KORNAŚ A., TOWPASZ K., GAWROŃSKI S. 1987. Dolina Wierzbanówki: 17. Zespoły leśne - The Wierzbanówka Valley: 17. Forest associations. Zesz. Nauk. Uniw. Jagiell., Pr. Bot. 17: 99-123. (in Polish with English summary)

MIREK Z., PIĘKOŚ-MIREK H., ZAJĄC A., ZAJĄC M. 2002. Flowering plants and pteridophytes of Poland. A checklist. Biodiversity of Poland. 1. W. Szafer Institute of Botany, Polish Academy of Sciences, Kraków, 442 pp.

OBERDOFFER E. 1992. Südeutsche Pflanzengesellschaften T.IV. Wälder und Gebüsche. G. Fischer Verl., Jena, Stuttgart, New York, 282 pp.

PODANI J. 2001. SYN-TAX 2000. Computer Programs for Data Analysis in Ecology and Systematics. Budapest, Scientia Publishing, 53 pp.

RÓŻAŃSKI W., PANCER-KOTEJOWA E., GRODZIŃSKA K. 1993. Vegetation of the Ratanica watershed (Carpathian Foothills, Southern Poland). Ekol. pol. 41 (3-4): 347-374.

STACHURSKA A. 1998. Zbiorowiska leśne północno-wschodniej części Pogórza Wielickiego (Zachodnie Karpaty) - Forest communities of the north-eastern part of the Wieliczka Foothills (Western Carpathians). Zesz. Nauk. Uniw. Jagiell., Pr. Bot. 30: 1-78 pp. (in Polish with English summary) 
TOWPASZ K. 1990. Charakterystyka geobotaniczna Pogórza Strzyżowskiego - Geobotanical description of the Strzyżów Foothills. Rozpr. Habil., 178, Uniw. Jagiell. 240 pp. (in Polish with English summary)

TRZCIŃSKA-TACIK H., STACHURSKA-SWAKOŃ A. 2002. Plant communities and their changes in the surroundings of the Dobczyce Reservoir (Southern Poland), In: Obrębska-Starkel B. (ed.). Topoclimatic and Geoecological Changes in the Wieliczka Foothills in the surrounding of the Dobczyce reservoir. Prace Geogr. 109: 31-72.
ZAJĄC A., ZAJĄC M. 2001. Atlas rozmieszczenia roślin naczyniowych Polski. - Distribution Atlas of Vascular Plants in Poland. Nakł. Pracowni Chorologii Komputerowej Instytutu Botaniki Uniwersytetu Jagiellońskiego, Kraków. (in Polish and English)

ZAJAC M., ZAJĄ A., ZEMANEK B. (eds). 2006. Flora Cracoviensis Secunda (Atlas). Nakł. Pracowni Chorologii Komputerowej Instytutu Botaniki Uniwersytetu Jagiellońskiego, Kraków, 291 pp. (in Polish and English) 